\title{
Hoe goed wordt de nieuwe claimbeoordeling Wajong?
}

J.J.M. Besseling

De kabinetsplannen om de Wajong aan te passen liggen sinds eind augustus bij de Raad van State en nadere details zijn nog niet bekend. Duidelijk is dat de uitvoeringspraktijk van de claimbeoordeling door verzekeringsarts en arbeidsdeskundige fors zal veranderen. Hoewel de eerste stap, de beoordeling van het verdienvermogen, niet wijzigt, is de totale beoordeling en advisering wel anders. De volgende beoordeling is namelijk of betrokkene over arbeidsvermogen beschikt en daarom in aanmerking komt voor de Wajong Werkregeling. UWV, in casu de verzekeringsarts en arbeidsdeskundige, stelt dan een participatieplan op. Het opstellen van het participatieplan vraagt om intensieve samenwerking tussen arbeidsdeskundige en verzekeringsarts. Vooral de visie op de cliënt aangaande sterke en zwakke punten in relatie tot arbeid is niet het domein van één van beiden maar een gezamenlijk domein. Ze zullen zich beargumenteerd en gedetailleerd moeten uitspreken over de prognose, de maximaal haalbare participatie en zij zullen de kritische succesfactoren veel meer moeten expliciteren dan nu het geval is. Hierbij zullen veel kritische succesfactoren buiten het sociaal-medische domein liggen.

UWV staat voor de uitdaging om dit werkproces voor te bereiden en in te richten en daarbij de uitvoerders van de benodigde tijd, kennis en middelen te voorzien. Hierbij gaan politieke afwegingen en keuzes een rol spelen. Maar inhoudelijk is het wenselijk om de uitvoeringspraktijk van instrumenten te voorzien die de beoordeling en advisering zo evidence based mogelijk maken. Te denken valt aan een geva- lideerd beoordelingsinstrument om arbeidsvermogen in kaart te brengen met een uitwerking rond de indicering en de criteria. Het is onwaarschijnlijk dat het Claimbeoordelings- en Borgingssysteem (CBBS) daartoe aangepast kan worden, aangezien het CBBS een instrument is om verdiencapaciteit in functies op de reguliere arbeidsmarkt vast te stellen op basis van de mogelijkheden zoals de verzekeringsarts die heeft vastgelegd in de FML en de rapportage.

Ook voor het opstellen van een participatieplan zal er behoefte zijn aan nadere informatie, bijvoorbeeld over prognoses van arbeidsvermogen en over succesvolle interventies gericht op het maximaliseren van het arbeidsvermogen van jongeren met een beperking. Het is een domein waarin nog weinig uitgekristalliseerde wetenschappelijke kennis is en waarin vooral praktijkervaringen sturend zijn. UWV is weliswaar bezig om een richtlijn op te stellen voor de Wajong-beoordeling, maar de beroepsgroep van verzekeringsartsen ontbeert nog protocollen die specifiek zijn voor de doelgroep Wajong.

Het zal een uitdaging zijn voor UWV om bij het uitwerken van dit nieuwe onderdeel van de Wajong-claimbeoordeling politiek, wetenschap en uitvoering gezamenlijk tot een nieuwe uitvoeringspraktijk te laten komen. Een 'goede' uitvoeringspraktijk die recht doet aan de politieke wens van een hogere arbeidsparticipatie van de jongeren met een beperking en die in staat is om kwalitatief goed te beoordelen en te adviseren op basis van inzichten en instrumenten die evidence based zijn. Of zal het straks toch zo zijn: de politiek heeft ambities, de uitvoering heeft mogelijkheden én beperkingen, en de wetenschappelijke onderbouwing ijlt na. 